\title{
Research Article \\ Optimizing the nitrogen fertilizer requirement for pre- release short duration rice cultures in North Eastern zone of Tamil Nadu
}

\author{
C. Muralidaran, S. Malathi and S. Banumathy
}

\begin{abstract}
SUMMARY
Field experiments were conducted for two years during 2017 and 2018 at Rice Research Station, Tirur to optimize nitrogen fertilizer requirement for pre-release rice cultures TM10085, TM 07335, TM 07030 along with the check variety CO51. The trial was conducted in split plot design with three replications and the main plot consisted of three pre-released rice cultures along with one check variety. The sub plot consisted of three fertilizers doses viz., $150-50-50 \mathrm{NPK} \mathrm{kg} / \mathrm{ha}, 175-50$ $50 \mathrm{NPK} \mathrm{kg} / \mathrm{ha}$ and $125-50-50 \mathrm{NPK} \mathrm{kg} / \mathrm{ha}$. In this experiment, the rice culture TM10085, along with fertilizer application of $150-50-50 \mathrm{NPK} \mathrm{kg} / \mathrm{h}$ a recorded the highest grain yield of $5505 \mathrm{~kg} / \mathrm{h}$ during 2018 . This treatment also registered highest growth, yield attributes and benefit cost ratio in Tirur, Tiruvallur district of North Eastern Zone, Tamil Nadu.
\end{abstract}

Key Words : Rice, Fertilizer dose, Nitrogen requirement, Pre-release cultures

How to cite this article : Muralidaran, C., Malathi, S. and Banumathy, S. (2021). Optimizing the nitrogen fertilizer requirement for pre-release short duration rice cultures in North Eastern zone of Tamil Nadu. Internat. J. Plant Sci., 16 (2): 126-130, DOI: 10.15740/ HAS/IJPS/16.2/126-130, Copyright@ 2021: Hind Agri-Horticultural Society.

Article chronicle : Received : 02.03.2021; Revised : 21.04.2021; Accepted : 01.05.2021

Email : cmuralidaran@gmail.com

Address of the Co-authors:

S. Malathi and S. Banumathy, Rice Research Station, Tamil Nadu Agricultural University, Tirur, Tiruvallur (T.N.) India

Email : malathi_agri@rediffmail.com 